\section{Is it possible to estimate longevity through the analyses used to measure the initial physiological potential in soybean seeds?}

\author{
Thiago Barbosa Batista*1 (iD) Samara Moreira Perissato ${ }^{1}$ (D) , Carlos Henrique \\ Queiroz Rego² (D), Gustavo Roberto Fonseca de Oliveira ${ }^{1}$ (D), Fernando \\ Augusto Henning ${ }^{3}$ (D) Edvaldo Aparecido Amaral da Silva ${ }^{1}$
}

ABSTRACT: The analysis of longevity can support decisions about the length of seed lot storage until commercialization, since this characteristic implies the maintenance of viability over time. Seed longevity is analyzed by the p50 test, which expresses the time to lose $50 \%$ of the initial viability. Seeds with high vigor and germination have greater physiological potential and, thus, a greater capacity to maintain quality throughout the storage period. However, there has been little research on the correlations between the analysis of p50 (longevity) and the tests used to measure physiological potential (germination and vigor) of lots, which can be used as a tool to make inferences about longevity using the most traditional tests. Thus, the objective of this study was to investigate which tests used to measure the potential of lots can estimate p50. To this end, germination and vigor were evaluated using traditional tests while longevity was assessed in eight soybean seed lots. Correlations and linear regression were tested for the traditional variables versus p50. It was found that the use of accelerated aging, electrical conductivity, and time to $50 \%$ radicle protrusion has high potential to estimate longevity as measured by $\mathrm{p} 50$.

Index terms: seed conservation, storage, physiological performance.

RESUMO: A análise da longevidade de um lote de sementes pode auxiliar na decisão de por quanto tempo armazenar um lote de sementes até a sua comercialização, uma vez que esta característica implica na manutenção da viabilidade ao longo do tempo. A longevidade é analisada pelo teste de p50, o qual representa o tempo para perda de $50 \%$ da viabilidade inicial. Sementes com elevada germinação e vigor têm maior potencial fisiológico e, assim, maior capacidade de manter a qualidade ao longo do período de armazenamento. No entanto, pouco tem sido estudado quanto às correlações entre a análise do p50 (longevidade) com os testes utilizados para mensurar o potencial fisiológico de lotes (germinação e vigor), o que pode ser utilizado como ferramenta para obter inferências sobre a longevidade por meio dos testes mais comumente utilizados. Assim, objetivou-se investigar quais testes utilizados para mensurar o potencial fisiológico de lotes pode ser utilizado para estimar o p50. Para isso, foram avaliados a germinação e o vigor, utilizando-se testes tradicionais e, em paralelo, a longevidade em oito lotes de sementes de soja. As correlações e a regressão linear para as variáveis tradicionais versus p50 também foram testadas. Foi verificado que o uso dos testes de envelhecimento acelerado, condutividade elétrica e tempo para $50 \%$ de protrusão da radícula tem elevado potencial para estimar a longevidade mensurada pelo p50.

Termos para indexação: conservação de sementes, armazenamento, performance fisiológica.
Journal of Seed Science, v.43, e202143024, 2021

http://dx.doi.org/10.1590/ 2317-1545v43249697
$*$ Corresponding author
E-mail: batistatb@hotmail.com

Received: 3/10/2021. Accepted: 7/8/2021.

${ }^{1}$ Universidade Estadual Paulista (UNESP), Departamento de Produção Vegetal, 14884-900 Botucatu, São Paulo, Brasil.

${ }^{2}$ Universidade de São Paulo (USP), Escola Superior de Agricultura Luiz de Queiroz, 13418-900 - Piracicaba, São Paulo, Brasil.

${ }^{3}$ EMBRAPA Soja, Caixa Postal 231, 86001-970 - Londrina, Paraná, Brasil. 


\section{INTRODUCTION}

For soybeans, the use of high-quality seeds results in an increase by up to $10 \%$ in production (França-Neto et al., 2012). Bagateli et al. (2019) reported that each point of increase in vigor level in soybean seeds can increase grain yield by up to 28 $\mathrm{kg}$ per hectare. Thus, the production and use of high-performance soybean seeds have a direct impact on the establishment and productivity of this legume.

In Brazil, soybean seed lots are marketed with a minimum germination rate of $80 \%$ (Brasil, 2013). In addition, internal quality control in each laboratory explores the potential of the seeds from each lot on the basis of vigor, which is most commonly analyzed by the following tests: tetrazolium, accelerated aging, seedling performance and electrical conductivity (Marcos-Filho, 2015a; Matera et al., 2019).

However, physiological quality does not only refer to germination and vigor, but also includes longevity, which is related to the ability of seeds to maintain their viability over time (Sano et al., 2016). This component is considered to ensure the dispersion of the species in the environment and the propagation of genetic resources, from germplasm banks to safe sowing of large areas after storage time in the seed industry.

Longevity is traditionally measured by p50 (time to 50\% loss of initial viability) (Ellis and Roberts, 1980). The information collected by determining p50 can help to define a seed lot in terms of its ability to preserve viability during storage, which can be particularly interesting to support decisions about the commercialization of seed lots. In addition, this analysis has been used to study the process of acquisition of seed longevity during maturation stages and to provide further information on the molecular mechanisms involved (Righetti et al., 2015; Lima et al., 2017; Basso et al., 2018). Thus, this test is very important and has great potential, and it can be a relevant tool for improvement programs whose goal is to produce high-quality cultivars in terms of the physiological quality of seeds.

However, in seed analysis laboratories, seed lot longevity is not commonly assessed because a long period of time is required to achieve the results, and seed analysts need previous training. Therefore, one way to make inferences about seed longevity is to identify which test - among those traditionally used to assess the physiological potential of soybean seeds - can correlate with p50 (longevity). This relationship may be possible, since the vigor level of soybean seeds not only declines faster than viability, but also influences their retention during storage (Egli et al., 1978).

Thus, the present study aimed to investigate the possibility of estimating longevity as determined by $\mathrm{p} 50$ in a simplified manner through the tests commonly used to measure the initial physiological potential of soybean seed lots.

\section{MATERIAL AND METHODS}

This study was carried out at the Seed Analysis Laboratory of the Plant Production Department, Universidade Estadual Paulista Júlio de Mesquita Filho (UNESP). Eight lots of soybean seeds from four cultivars were used: L1, L2, L3 (AS3730), L4, L5 (CD2728), L6 (NA5909), L7 and L8 (DM6458), produced and donated by the Brazilian Agricultural Research Corporation - EMBRAPA Soja (Londrina, PR). First, according to the criteria established by Pinto et al. (2018), seeds were discarded when their size was $<0.8 \mathrm{~mm}$ in comparison to average lot size. After homogenization, the seed lots were stored in a chamber at $10{ }^{\circ} \mathrm{C}$ and $45 \%$ relative humidity $(\mathrm{RH})$ for a period of 180 days until the following tests were performed.

Moisture content: evaluated at $105^{\circ} \mathrm{C}$ for 24 hours (Brasil, 2009), using two replicates of ten seeds. The result was expressed in degrees of moisture on a wet basis.

Germination: seven samples of fifty seeds were germinated on a paper towel moistened with water at 2.5 times the dry paper weight at $25^{\circ} \mathrm{C}$. Germination percentage was evaluated by counting normal seedlings in the fifth (first germination count (FG)) and on the eighth day (total germination (G)), according to the Rules for Seed Testing (Brasil, 2009).

Seedling vigor classification (SV): seedlings from the first germination count were classified as "strong" and "weak" according to the criteria established by Krzyzanowski et al. (2020). The result was expressed as percentage of "strong" 
normal seedlings at five days according to Matera et al. (2019).

Radicle protrusion (RP): performed together with the germination test. The result of the total number of seeds whose radicle was $\geq 2 \mathrm{~mm}$ (Faria et al., 2020) was counted on the eighth day after the installation of the test. The result was expressed in percentage of seeds with radicle protrusion.

Time to 50\% radicle protrusion (t50): seven samples of 25 seeds from each lot were germinated in a Petri dish, using paper towel moistened with water at 2.5 times the dry paper weight as substrate, at $25{ }^{\circ} \mathrm{C}$. The evaluations were carried out every six hours by counting the number of seeds whose radicle was $\geq 2 \mathrm{~mm}$ until the fifth day after installation. Time required for $50 \%$ of seed radicle protrusion was calculated by analyzing cumulative protrusion data, using the curve fitting module of the Germinator Software (Joosen et al., 2010).

Tetrazolium: performed with seven samples of 25 seeds. The samples were moistened as described for the germination test for a period of sixteen hours. Afterwards, the seeds were immersed in a $0.075 \%$ tetrazolium salt solution for a period of two hours at $40^{\circ} \mathrm{C}$, in the dark. After this period, the samples were washed and immersed in water for a period not exceeding seven hours for evaluations. The viability (TZVB) and vigor (TZVG) classification system was used according to the criteria established by França-Neto and Krzyzanowski, 2018.

Accelerated aging (AA): conducted following the criteria established by Marcos-Filho (1999); seven samples of fifty seeds were placed in single layers on the surface of a wire mesh suspended over $40 \mathrm{~mL}$ of distilled water (100\% RH) inside a plastic box $(11 \times 11 \times 3 \mathrm{~cm})$. Subsequently, the plastic boxes were incubated in a chamber at $41^{\circ} \mathrm{C}$ for 48 hours. After this period, the seeds were left to germinate according to the methodology described above for the germination test. Normal seedlings were counted on the fourth day after test installation. After the aging period, the moisture content of the seeds was determined according to the method described above, and it was $27 \pm 1 \%$.

Electrical conductivity (EC): performed with seven samples of 25 seeds per lot, with known mass values. The seeds were immersed in $75 \mathrm{~mL}$ of distilled water inside a plastic container, and then incubated at $25^{\circ} \mathrm{C}$ for 24 hours. After this period, the electrical conductivity of the solutions was measured with a conductivity meter (model Digimed D31). The result was expressed in $\mu \mathrm{S} . \mathrm{cm}^{-1}$. $\mathrm{g}^{-1}$; reading values were divided by seed mass (Vieira and Krzyzanowski, 1999).

Seed performance by computerized image analysis of seedlings (Vigor-S $\left.{ }^{\circledR}\right)$ : seven samples of twenty seeds were placed in two rows of ten seeds each, in the upper third of the paper towel moistened in water 2.5 times the dry paper weight. The rolls containing the seeds were incubated at $25{ }^{\circ} \mathrm{C}$ for three days. At the end of this period, the seedlings from each sample were placed on a sheet of blue ethyl vinyl acetate and scanned using an inverted scanner in a metal box. Images were generated at $300 \mathrm{DPI}$ and analyzed using the software Vigor- $\mathrm{S}^{\circledR}$, following the parameters described by Rodrigues et al. (2020) to calculate vigor index, growth index, development uniformity index and seedling length.

Seedling emergence in sand $(E)$ : seven samples of fifty seeds were sown in trays containing sand substrate moistened to $60 \%$ of its water holding capacity. The seeds were distributed in the substrate and sown at a depth of $3 \mathrm{~cm}$. On the fifteenth day after sowing, total emergence percentage was determined, considering as emerged the seedlings whose cotyledons were projected above the substrate surface and with separate unifoliate leaves.

Longevity: determined by time to $50 \%$ loss of viability, according to the methodology of Batista et al. (2020): the seeds were distributed on the surface of a wire mesh over a saturated solution of $\mathrm{NaCl}(75 \% \mathrm{RH})$ in hermetically sealed plastic boxes $(21 \times 14 \times 7 \mathrm{~cm})$ at $35{ }^{\circ} \mathrm{C}$. Seed viability was evaluated through the germination test described above, throughout the storage period (which depended on the behavior of loss of viability of each analyzed lot), using seven samples of fifty seeds for each lot. Radicle protrusion percentage $\geq 2 \mathrm{~mm}$ was measured on the eighth day after test installation. Radicle protrusion was used as a viability criterion during storage as it is the last physiological characteristic to be lost as deterioration progresses. Based on the results found during storage, the viability distribution curve for each lot was adjusted for sigmoidal behavior and the viability data were transformed into probits to determine p50, using the equation proposed by Ellis and Roberts (1980): $v=(\mathrm{Ki}-\mathrm{p}) / \sigma$.

Statistical analysis: the significance of p50 of the analyzed lots was checked using the F-test $(\alpha=0.05)$. Pearson's simple correlation $(r)$ was performed at a confidence level of 0.05 . The simple linear regression analysis equations were 
obtained by relating the independent variables (time to $50 \%$ germination, electrical conductivity and accelerated aging) with p50 as the dependent variable. The F-test was used in the resulting equations to test their significance $(\alpha=0.01)$. Pearson's coefficient and simple linear regression were interpreted according to Zou et al. (2003).

\section{RESULTS AND DISCUSSION}

Loss of viability during storage was adjusted to the sigmoid behavior (Figure 1A). By determining viability over time, significance $(\alpha<0.05)$ was found for the p50 values of the analyzed lots (Figure 1B). This finding is due to the fact that longevity is extremely dependent on environmental conditions during seed development, especially in the maturation and late maturation phases (Righetti et al., 2015), and also on post-maturation factors, e.g., harvest time and seed processing and characteristics of the genotype itself.

Loss of viability during storage is initially asymptomatic, considering that germination remains at $80 \%$ during the initial period of the test (Fleming et al., 2019), as also found in the lots analyzed in this study (see the line shown on the y axis in Figure 1A). Thus, longevity is difficult to analyze under ideal storage conditions when considering the total period during which the seeds can remain viable. In soybean seeds, this period can be around 24 years (Fleming et al., 2017).

Based on this fact, p50 is commonly used to investigate this component more rapidly (Ellis and Roberts, 1980; Lima et al., 2017; Basso et al., 2018; Santos et al., 2019; Faria et al., 2020; Batista et al., 2020). However, there have been few analyses about the relationship of this test with other tests more commonly used to measure the physiological potential of soybean seeds. Therefore, the following results are particularly noteworthy.

First, Pearson's correlation analysis showed that the determination of $\mathrm{p} 50$ (longevity) has a weak positive correlation $(r<0.5)$ with the initial viability in commercial soybean lots, measured by germination tests, radicle protrusion and the indexes generated via TZ (TZVB and TZVG) (Table 1). This result is significant, since germination analysis is the priority requirement for the commercialization of seeds, which must reach the minimum standard of $80 \%$ of germination (Brasil, 2013). As checked, there were no implications on the storage capacity of soybean seeds.

Vigor by TZ (TZVG) is a robust index to classify the vigor level of soybean seed lots, and its weak correlation with longevity may have been due to the distinctions between the components evaluated by the test (mechanical damage, damage by moisture and bug damage) with the storage capacity of soybean seeds, which should be explored in future research.
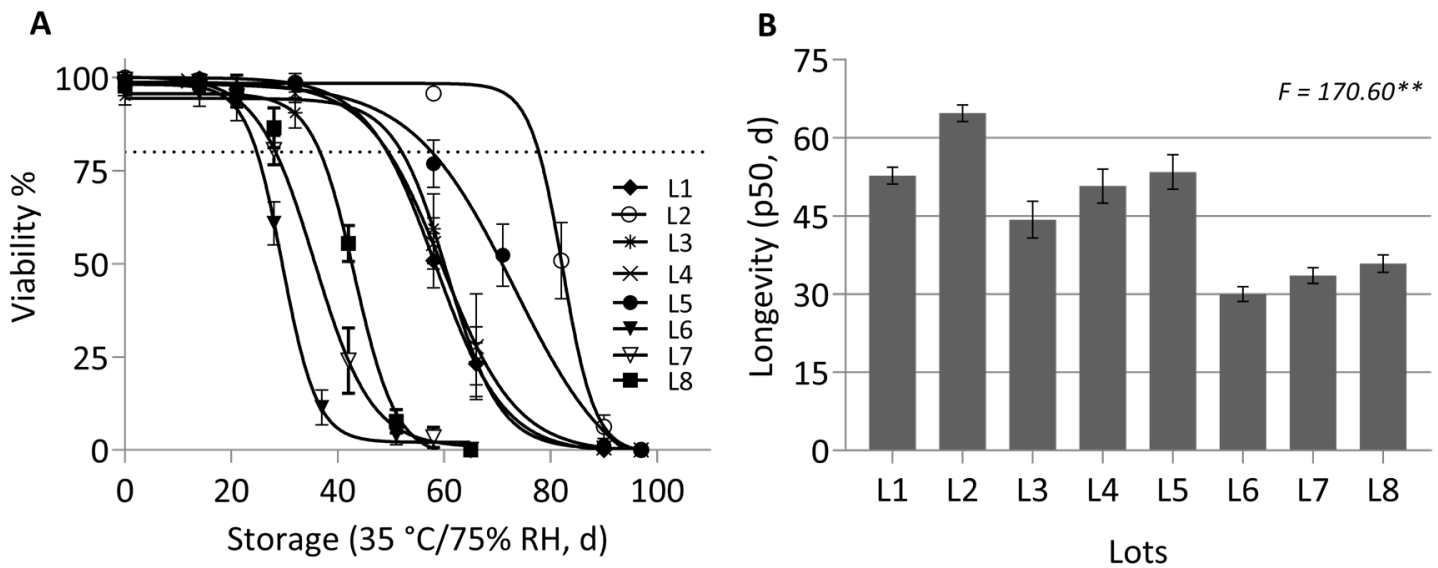

**: indicates the significance of the variance by the F-test $(\alpha=0.05)$. Bars represent the standard deviation of the sample.

Figure 1. Viability during storage at $35^{\circ} \mathrm{C} / 75 \% \mathrm{RH}(\mathrm{A})$ and longevity (p50) (B) in soybean seeds. Germination during storage was adjusted using the parameters of the Boltzmann equation $[y=$ top $+($ bottom - top $) / 1+[v 50-$ $(x /$ slope $)]]$. 
Table 1. Pearson's correlation coefficient ( $r$ ), $P$-value and significance between p50 (longevity) and traditional tests used to analyze the performance of soybean seed lots.

\begin{tabular}{lcc}
\hline & $r$ & $\mathrm{P}$ \\
\hline p50 vs. First germination count & 0.344 & 0.009 \\
p50 vs. Germination & 0.239 & 0.075 \\
p50 vs. Seedling vigor & 0.252 & 0.060 \\
p50 vs. Radicle protrusion & 0.207 & 0.1244 \\
p50 vs. Time to 50\% germination & -0.836 & $<0.0001$ \\
p50 vs. Accelerated aging & 0.858 & $<0.0001$ \\
p50 vs. Electrical conductivity & -0.808 & $<0.0001$ \\
p50 vs. Vigor by the tetrazolium test & 0.370 & 0.0049 \\
p50 vs. Viability by the tetrazolium test & 0.323 & 0.0150 \\
p50 vs. Emergence & 0.176 & 0.1920 \\
p50 vs. Vigor index & 0.671 & $<0.0001$ \\
p50 vs. Seedling length & 0.568 & $<0.0001$ \\
p50 vs. Uniformity & 0.622 & $<0.0001$ \\
\hline
\end{tabular}

Although frequently used in internal control, seedling emergence did not match $p 50$, which may have due to the fact that this test is extremely dependent on environmental conditions and testing methodology, which makes it difficult to observe how it relates to the other tests. Matera et al. (2019) found no substantial correlation between seedling emergence in sand with the other vigor tests in soybean seeds, which supports the results found in the present study (Table 1).

For the data collected using the Vigor-S analysis, there was a moderate positive correlation $(r>0.5)$ with p50 (Table 1). The responses obtained through seedling length are based on the efficiency of the process of translocation of storage tissue reserves for the growth of the embryonic axis, which is larger in vigorous seeds (Delouche and Baskin, 1973).

Furthermore, the indexes generated by Vigor-S have been recommended for the accuracy of the results for the vigor of soybean seed lots, as reported by Rodrigues et al. (2020). This analysis can be made in a quick and streamlined manner; as shown in the present study, the software provides robust results that have moderate implications for the storage capacity of soybean seeds.

In contrast to previous findings, there was a strong positive correlation ( $r>0.8$ ) between p50 (longevity) and the accelerated aging test and a strong negative correlation $(r<0.8)$ between electrical conductivity and time to $50 \%$ radicle protrusion (Table 1 ), which are inversely proportional. Linear regression was performed to estimate p50 using these variables (Table 2), which were selected owing to their strong correlations with p50 (Table 1), as it has been found that there can be no adequate adjustments with moderate and weak correlations (Matera et al., 2019; Prado et al., 2019). Thus, satisfactory adjustments of $r^{2}$ were found for linear equations obtained from accelerated aging $\left(r^{2}=0.73\right)$, time to $50 \%$ radicle protrusion $\left(r^{2}=0.70\right)$ and electrical conductivity $\left(r^{2}=0.69\right)$ (Table 2$)$.

In practical terms, lot 4 was used as a case for analysis (lot with intermediate p50 value), in which accelerated aging, electrical conductivity and time to $50 \%$ protrusion were $56 \%, 67.48 \mu \mathrm{S} \mathrm{cm}^{-1} \cdot \mathrm{g}^{-1}$ and $46 \mathrm{~h}$, respectively (data not shown). The p50 value for lot 4 was 51 days (Figure $1 B$ ). Using the resulting equations (Table 2 ), the estimated p50 value was: (i) 49 days using accelerated aging [18.429+ $(0.543 * 56 \%)$ ], (ii) 47 days using electrical conductivity [96.686 - $(0.740$ $\left.* 67.48 \mu \mathrm{S} . \mathrm{cm}^{-1} \cdot \mathrm{g}^{-1}\right)$ ] and (iii) 49 days using time to 50\% protrusion [111.923 $-(1.363 * 46 \mathrm{~h})$ ]. The greatest accuracy was achieved using accelerated aging and time to $50 \%$ protrusion, possibly owing to the strong adjustment of their equation and their smaller estimation errors (Table 2). However, this estimate should be used to rank the storage potential values among lots. 
Table 2. Regression equations, coefficients of determination $\left(r^{2}\right), F$-test, $P$-value and standard error of the estimate for the dependent variable (longevity (p50)) on the basis of the independent variables (time to $50 \%$ protrusion (t50), accelerated aging (AA) and electrical conductivity (EC)).

\begin{tabular}{cccc}
\hline Equation $(y=\alpha+\beta . x)$ & $r^{2}$ & F-test & Standard error of estimate \\
\hline $\mathrm{p} 50=111.923-1.363^{*} \mathrm{t} 50$ & 0.70 & $130.2^{*}$ & 6.24 \\
$\mathrm{p} 50=18.429+0.543^{*} \mathrm{AA}$ & 0.73 & $151.8^{*}$ & 5.91 \\
$\mathrm{p} 50=96.686-0.740 * \mathrm{EC}$ & 0.69 & $79.5^{*}$ & 7.34 \\
\hline
\end{tabular}

*Significant at 0.01 probability.

Accelerated aging is commonly used to measure vigor through the advanced process of deterioration, caused by high humidity and high temperature (Marcos-Filho, 2015b), and it has the potential to determine seed longevity (Marcos-Filho, 2015a). However, little information has been reported about its relationship with soybean seed viability. This may be due to the fact that the conditions for accelerated aging in soybean seeds makes deterioration more drastic as it increases the moisture content in seeds - usually by $20 \%$ - while they are exposed to a temperature around $41^{\circ} \mathrm{C}$. In contrast to the conditions adopted for analyzing longevity, it allows for a slower progression of deterioration and more easily resembles the distribution of seed viability over time (desirable in the study of this attribute) since seed moisture content stabilizes at $12 \%$ at a temperature of $35^{\circ} \mathrm{C}$ in the testing environment.

However, the results found in the present study can validate the accelerated aging test to provide further insights into soybean seed longevity, since there was a strong correlation between longevity (p50) and the accelerated aging test (Table 1) and a positive linear relationship between them (Table 2). This behavior was also reported by Fenollosa et al. (2020) when analyzing the possibility of using accelerated aging to estimate the longevity of Carpobrotus edulis seeds.

Electrical conductivity showed the same potential (Table 1). This test is based on the fact that, during the absorption of water by the seeds until the occurrence of cell membrane organization, there is a loss of sugars, enzymes, nucleotides, fatty acids, amino acids, proteins and organic compounds, and the greater the level of seed deterioration, the longer the time to organize the membranes and the consequent increase in such losses (Prado et al., 2019). Thus, the greater the level of membrane organization, that is, the lower the electrical conductivity reading, the greater the seed vigor and seed lot longevity (observed in this study), thus reflecting a lower level of deterioration.

These results show that by identifying the initial level of deterioration using the accelerated aging and electrical conductivity test, inferences can be made about the storage capacity (p50, days) of the soybean seed lot (Tables 1 and 2). These tests have been reported to be robust in predicting the physiological potential of soybean seed lots (Matera et al., 2019; Prado et al., 2019). As demonstrated in the present study, inferences can be made about p50 using the resulting equations (Table 2), which was not possible with the traditional germination analysis.

Time to $50 \%$ radicle protrusion is not usually used to integrate the internal quality control of soybean seeds and is currently restricted to scientific research. This evaluation is based on the slow germination of less vigorous seeds, which is due to increased time between the start of water uptake and radicle emergence (Marcos-Filho, 2015b). Therefore, the results of this study reveal two important facts: (i) time to $50 \%$ radicle protrusion needs to be validated to integrate routine analyses, since such information is collected in a short period of time. This depends, however, on the inclusion of computer vision assessment, as currently done for tomato seeds (Oliveira et al., 2020), as this test requires counting at short intervals, which makes it difficult to be included in routine laboratory analyses. Finally, (ii) t50 can be used to estimate the storage capacity of soybean seeds (Tables 1 and 2).

The present results demonstrate that inferences about the storage capacity of soybean seeds as measured by p50 can be included in traditional analyses, following the strong associations between longevity and vigor of soybean seeds. Therefore, these results can be used to improve the process of internal quality control in a seed analysis laboratory; in addition, they can potentially contribute information to decision-making processes in soybean seed companies. 


\section{CONCLUSIONS}

The accelerated aging, time to $50 \%$ radicle protrusion and electrical conductivity tests can be used to estimate soybean seed longevity.

\section{ACKNOWLEDGEMENTS}

To Dr. João Nakagawa for his contributions to this study. To the team involved in the SeedSoy project of the Embrapa Management System, for the production of seeds used in the research. To the Fundação de Amparo à Pesquisa do Estado de São Paulo (FAPESP) for granting a doctoral scholarship to the first author (grant number 2019/06160-6) and for funding the project (grant number 2017/50211-9); and to the Conselho Nacional de Desenvolvimento Cientifico e Tecnológico (CNPq) for offering a research grant to E. A. Amaral da Silva (protocol n. 309718/2018-0).

\section{REFERENCES}

BAGATELI, J.R.; DÖRR, C.S.; SCHUCH, O.B.; MENEGHELLO, G.E. Productive performance of soybean plants originated from seed lots with increasing vigor levels. Journal of Seed Science, v.41, n.2, p.151-159, 2019. https://doi.org/10.1590/2317-1545v41n2199320

BASSO, D.P.; HOSHINO-BEZERRA, A.A.; SARTORI, M.M.; BUITINK, J.; LEPRINCE, O.; SILVA, E.A.A. Late seed maturation improves the preservation of seedling emergence during storage in soybean. Journal of Seed Science, v.40, n.2, p.185-192, 2018. https://doi. org/10.1590/2317-1545v40n2191893

BATISTA, T.B.; FERNANDEZ, J.J.; SILVA, T.A.; MAIA, J.; SILVA, E.A.A. Transcriptome analysis in osmo-primed tomato seeds with enhanced longevity by heat shock treatment. AoB Plants, v.12, n.5, p.1-10, 2020. https://doi.org/10.1093/aobpla/plaa041

BRASIL. Ministério da Agricultura, Pecuária e Abastecimento. Padrões para produção e comercialização de sementes de soja. Ministério da Agricultura, Pecuária e Abastecimento. Secretaria de Defesa Agropecuária. Brasília: MAPA/ACS. Instrução normativa n.45, de 17 de setembro de 2013. https://www.gov.br/agricultura/pt-br/assuntos/insumos-agropecuarios/insumos-agricolas/ sementes-e-mudas/publicacoes-sementes-e-mudas/copy_of_INN45de17desetembrode2013.pdf

BRASIL. Ministério da Agricultura, Pecuária e Abastecimento. Regras para análise de sementes. Ministério da Agricultura, Pecuária e Abastecimento. Secretaria de Defesa Agropecuária. Brasília: MAPA/ACS, 2009. 399p. http:// https://www.gov.br/agricultura/ptbr/assuntos/insumos-agropecuarios/arquivos-publicacoes-insumos/2946_regras_analise_sementes.pdf

DELOUCHE, J.C.; BASKIN, C.C. Accelerated aging techniques for predicting the relative storability of seed lots. Seed Science and Technology, v.1, p.427-452, 1973. https://ir.library.msstate.edu/bitstream/handle/11668/13316/F-4. pdf?sequence=1

EGLI, D.B.; WHITE, G.M.; TEKRONY, D.M. Relationship between seed vigor and the storability of soybean seed. Journal of Seed Technology, v.3, n.2, p.1-11, 1978. https://doi.org/10.2135/cropsci1977.0011183X001700040023x

ELLIS, R.H.; ROBERTS, E.H. Improved equations for the prediction of seed longevity. Annals of Botany, v.45, n.1, p.13-30, 1980. https://doi.org/10.1093/oxfordjournals.aob.a085797

FARIA, R.Q.; SANTOS, A.R.P.; AMORIN, D.J.; CANTÃO, R.F.; SILVA, E.A.A.; SARTORI, M.M.P. Probit or logit? Which is the better model to predict the longevity of seeds? Seed Science Research, v.30, n.1, p.49-58, 2020. https://doi.org/10.1017/S0960258520000136

FENOLLOSA, E.; JENÉ, L.; MUNNÉ-BOSCH, S. A rapid and sensitive method to assess seed longevity through accelerated aging in an invasive plant species. Plant Methods, v.16, p.1-11, 2020. https://doi.org/10.1186/s13007-020-00607-3

FLEMING, M.B.; HILL, L.M.; WALTERS, C. The kinetics of ageing in dry-stored seeds: a comparison of viability loss and RNA degradation in unique legacy seed collections. Annals of Botany, v.123, n.7, p.1133-1146, 2019. https://doi.org/10.1093/aob/mcy217

FLEMING, M.B.; RICHARDS, C.M.; WALTERS, C. Decline in RNA integrity of dry-stored soybean seeds correlates with loss of germination potential. Journal of Experimental Botany, v.68, n.9, p.2219-2230, 2017. https://doi.org/10.1093/jxb/erx100

FRANÇA-NETO, J.B. KRZYZANOWSKI, F.C. Metodologia do teste de tetrazólio em semente de soja. 1st ed. Londrina: Embrapa SojaDocumentos (INFOTECA-E), 2018. 108p. 
FRANÇA-NETO, J.B.; KRZYZANOWSKI, F.C.; HENNING, A.A. Plantas de alto desempenho e a produtividade da soja. Seed News, v.16, n.6, p.8-11, 2012. https://www.embrapa.br/busca-de-publicacoes/-/publicacao/940086/plantas-de-alto-desempenho-e-aprodutividade-da-soja

JOOSEN, R.V.L.; KODDE, J.; WILLEMS, L.A.J.; LIGTERINK, W.; VAN DER PLAS, L.H.W.; HILHORST, H.W.M. Germinator: a software package for high-throughput scoring and curve fitting of Arabidopsis seed germination. The Plant Journal, v.62, n.1, p.148-159, 2010. https://doi.org/10.1111/j.1365-313X.2009.04116.x

KRZYZANOWSKI, F.C; FRANÇA-NETO, J.B.; GOMES-JUNIOR, F.G.; NAKAGAWA, J. Testes de vigor baseados em desempenho das plântulas. In: KRZYZANOWSKI, F.C.; VIEIRA, R.D.; MARCOS-FILHO, J.; FRANÇA-NETO, J.B. (ed). Vigor de sementes: conceitos e testes. Londrina: ABRATES, 2020. p.104-114.

LIMA, J.J.P.; BUITINK, J.; LALANNE, D.; ROSSI, R.F.; PELLETIER, S.; SILVA, E.A.A.; LEPRINCE, O. Molecular characterization of the acquisition of longevity during seed maturation in soybean. PloS one, v.12, n.7, p.1-25, 2017. https://doi.org/10.1371/journal. pone.0180282

MARCOS-FILHO, J. Fisiologia de sementes de plantas cultivadas. Londrina: ABRATES, 2015a. 660p.

MARCOS-FILHO, J. Seed vigor testing: an overview of the past, present and future perspective. Scientia Agricola, v.72, n.4, p.363374, 2015b. https://doi.org/10.1590/0103-9016-2015-0007

MARCOS-FILHO, J. Teste de envelhecimento acelerado. In: KRZYZANOWSKI, F.C.; VIEIRA, R.D.; FRANÇA-NETO, J.B. (ed.). Vigor de sementes: conceitos e testes. Londrina: ABRATES, 1999. p.1-24.

MATERA, T.C.; PEREIRA, L.C.; BRACCINI, A.L.; KRZYANOWSKI, F.C.; SCAPIM, C.A.; PIANA, S.C.; MARTELI, D.C.V.; PEREIRA, R.C.; FERRI, G.C.; SUZUKAWA, A.K. Accelerated aging test and its relationship to physiological potential of soybean seeds. Journal of Seed Science, v.41, n.3, p.301-308, 2019. https://doi.org/10.1590/2317-1545v41n3212746

OLIVEIRA, G.R.F.; SALLES, F.K.L.; BATISTA, T.B.; SILVA, M.S.; CICERO, S.M.; GOMES-JUNIOR, F.G. Morphological parameters of image processing to characterize primary root emergence in evaluation of tomato seed vigor. Journal of Seed Science, v.43, p.1-9, 2020. https://doi.org/10.1590/2317-1545v43245215

PINTO, C.A.G.; KRZYZANOWSKI, F.C.; FRANÇA-NETO, J.B.; DOURADO-NETO, D.; SILVA, C.B.; MARCOS-FILHO, J. Relation between size and physiological potential of soya bean seeds under water availability. Seed Science and Technology, v.46, n.3, p.497-510, 2018. http://dx.doi.org/10.15258/sst.2018.46.3.07

PRADO, J.P.; KRZYZANOWSKI, F.C.; MARTINS, C.C.; VIEIRA, R.D. Physiological potential of soybean seeds and its relationship to electrical conductivity. Journal of Seed Science, v.41, n.4, p.407-415, 2019. https://doi.org/10.1590/2317-1545v41n4214988

RIGHETTI, K.; VU, J.L.; PELLETIER, S.; VU, B.L.; GLAAB, E.; LALANNE, D.; PASHA, A.; PATEL, R.V.; PROVART, N.J.; VERDIER, J.; LEPRINCE, O.; BUITINK, J. Inference of longevity related genes from a robust coexpression network of seed maturation identifies regulators linking seed storability to biotic defense related pathways. Plant Cell, v.27, p.2692-2708, 2015. https://doi.org/10.1105/tpc.15.00632

RODRIGUES, M.; GOMES-JUNIOR, F.G.; MARCOS-FILHO, J. Vigor-S: system for automated analysis of soybean seed vigor. Journal of Seed Science, v.42, p.1-12, 2020. https://doi.org/10.1590/2317-1545v42237490

SANO, N.; RAJJOU, L.; NORTH, H.M.; DEBEAUJON, I.; MANION-POLL, A.; SEO, M. Staying alive: molecular aspects of seed longevity. Plant Cell Physiology, v.57, n.4, p.660-674, 2016. https://doi.org/10.1093/pcp/pcv186

SANTOS, A.R.P.; FARIA, R.Q.; AMORIM, D.J.; GIANDONI, V.C.R.; SILVA, E.A.; SARTORI, M.M.P. Cauchy, Cauchy-Santos-Sartori-Faria, Logit, and Probit Functions for estimating seed longevity in soybean. Agronomy Journal, v.111, n.6, p.2929-2939, 2019. https://doi. org/10.2134/agronj2018.11.0700

VIEIRA, R.D.; KRZYZANOWSKI, F.C. Teste de condutividade elétrica. In: KRZYZANOWSKI, F.C.; VIEIRA, R.D.; FRANÇA-NETO, J.B. (ed.). Vigor de sementes: conceitos e testes. Londrina: ABRATES, 1999. p.1-26.

ZOU, K.H.; TUNCALI, K.; SILVERMAN, S.G. Correlation and simple linear regression. Radiology, v.227, n.3, p.617-628, 2003. https:// doi.org/10.1148/radiol.2273011499 